Civic Education at ... (Suidat et al.)

\title{
CIVIC EDUCATION AT MUHAMMADIYAH HIGHER EDUCATION: DEVELOPMENT STUDY OF HAND BOOK OF MENUJU KEHIDUPAN YANG DEMOKRATIS DAN BERKEADABAN
}

\author{
Suidat, Didin Saefuddin, Adian Husaini, Endin Mujahidin \\ Doktor Pendidikan Islam Universitas Ibn Khaldun \\ E-Mail: 8suidattt@gmail.com
}

\begin{abstract}
Civic education is one of the basic courses that must be taken by every student at the College. The regulation of the course is based on the mandate contained in the law on the National Education System. Through Civic Education courses, the students can be directed national personality, that is how they love their homeland Indonesia, being a democratic, civilized, tolerant and so on. Muhammadiyah through the Council of Higher Education, Research and Development of Muhammadiyah head quarter published a textbook on Civic Education with the title Civic Education toward a Democratic and Civilized Life. The book became a staple in reference Civic Education Course in Universities of Muhammadiyah (PTM). However when elaborate on the Indonesian ideology or, in the book does not contain the formulation history of state basic ideology which was done by the founding fathers. Also how the role and Islamic thought figures who participated in formulating the state basic ideology be part of the material that was duly presented in the book. It is important that students who study in PTM to know and understand the history and struggle of Islamic figures in formulating the basis of the state and the dynamics that occurred at that time. So that their knowledge is complete and in understanding the Pancasila as the state basic ideology of Indonesia. Ki Bagus had very important role in the Committee for Indonesian Independence (PPKI) experienced of dead lock about the change of first principle of Pancasila, and there was serious debate and dynamic. Likewise, the role and thought of Kasman Singodimedjo was also important on the basis state in both the trial PPKI, as well as in the Constituent Assembly. Perpsektif Kasman about Pancasila based on Islam became important after the implementation of 1945 Constitution and Presidential Decree July $5^{\text {th }}$ 1959. The role of Abdul Kahar Mudzakkir as a witness to the history of the struggle of Muslims cannot be neglected; especially Mudzakkir included in the Committee of Nine which develops the basic state eventually became the Jakarta Charter and accepted unanimously by BPUPKI. Furthermore, in the Constituent Assembly Mudzakkir remain committed to make Islam as the basis of the state, where the Constituent Assembly is the foundation of the momentum of the second volume formulation. The core of the Civics book is how the problem of state ideology especially Pancasila can be described in a comprehensive, complete and not partial. Including the relationship between the Jakarta Charter and the Constitution 1945. Other matters concerning aspects of citizenship is derived and the meaning of ideology or basic state. Therefore, this paper presents the role and thought of Ki Bagus Hadikusumo, Kasman Singodimedjo, and Abdul Kahar Mudzakkir become material development of Civic Education in the book of Civic Education toward a Democratic and Civilized Life.
\end{abstract}

Key word: Civic education; Muhammadiyah Higher Education; Hand book

Abstrak: Pendidikan Kewarganegaraan merupakan salah satu mata kuliah dasar yang mesti ditempuh oleh setiap mahasiswa dalam studinya di Perguruan Tinggi. Ketentuan adanya mata kuliah ini berdasarkan amanat yang tertuang dalam undang-undang tentang Sistem Pendidikan Nasional. Melalui mata kuliah Pendidikan Kewarganegaraan ini mahasiswa diarahkan dapat berkepribadian nasional, yaitu bagaimana mereka cinta tanah air Indonesia, bersikap demokratis, beradab, toleran dan lain sebagainya. Muhammadiyah melalui 
Majelis Pendidikan Tinggi, Penelitian dan Pengembangan (Diktilitbang) Pimpinan Pusat Muhammadiyah (PP Muhammadiyah) menerbitkan satu buku teks tentang Pendidikan Kewarganegaraan (Civic Education) dengan judul Pendidikan Kewarganegaraan Menuju Kehidupan yang Demokratis dan Berkeadaban. Buku ini menjadi referensi pokok dalam Mata Kuliah Pendidikan Kewarganegaraan di Perguruan Tinggi Muhammadiyah (PTM). Akan tetapi ketika menguraikan tentang ideologi atau dasar negara Indonesia pada bagian yang membahas tentang "Membangun Identitas Nasional", tidak memuat bagaimana sejarah perumusan dasar negara yang dilakukan para founding fathers. Bagaimana pemikiran tokoh-tokoh Islam seperti Ki Bagus Hadikusumo, Kasman Singodimedjo, dan Abdul Kahar Mudzakkir tidak menjadi bagian dalam materi yang sepatutnya disajikan dalam buku tersebut. Hal ini penting agar mahasiswa mengetahui dan memahami sejarah dan perjuangan tokoh-tokoh Islam dalam merumuskan dasar negara serta dinamika yang terjadi saat itu. Sehingga pengetahuan mereka menjadi utuh dan tidak parsial dalam memahami Pancasila sebagai dasar negara Indonesia. Peran Ki Bagus sangat penting ketika Panitia Persiapan Kemerdekaan Indonesia (PPKI) mengalami deadlock soal perubahan sila pertama dasar negara Indonesia. Demikian juga pemikiran Kasman Singodimedjo tentang dasar negara baik dalam sidang PPKI, maupun dalam sidang Konstituante. Perpsektif Kasman tentang Pancasila yang berbasis pada Islam menjadi penting setelah diberlakukan kembali UUD 1945 dengan lahirnya Dekrit Presiden 5 Juli 1959. Demikian juga pemikiran Abdul Kahar Mudzakkir sebagai saksi sejarah perjuangan umat Islam tidak bisa dilupakan begitu saja, Abdul Kahar Mudzakkir termasuk dalam Panitia Sembilan yang bertugas menyusun dasar negara yang pada akhirnya menjadi Piagam Jakarta. Dalam Sidang Konstituante Mudzakkir tetap komitmen menjadikan Islam sebagai dasar negara, di mana Sidang Konstituante adalah momentum perumusan dasar negara jilid kedua. Inti dari buku PKn adalah bagaimana masalah ideologi negara khususnya Pancasila dapat dijelaskan secara komprehensif, utuh dan tidak parsial. Termasuk hubungan antara Piagam Jakarta dan UUD 1945. Oleh karena itu disertasi ini membahas pemikiran Ki Bagus Hadikusumo, Kasman Singodimedjo, dan Abdul Kahar Mudzakkir menjadi bahan pengembangan materi Pendidikan Kewarganegaraan dalam buku ajar Pendidikan Kewarganegaraan Menuju Kehidupan yang Demokratis dan Berkeadaban.

Kata kunci: Pendidikan Kewarganegaraan; Pendidikan Tinggi Muhammadiyah; Buku Ajar

\section{INTRODUCTION}

Civic education is one of the subjects that must be taken by every student in his/her study at the College. This course is usually given in the first semester. Condition of the course is based on the mandate contained in law, which states that higher education curriculum shall contain: Religious Education; Civic education; and language ${ }^{1}$. The obligation of giving the Civic Education course reaffirmed in Government Regulation No. 19 of 2005 on National Education Standards, that the Higher Education Unit Level Curriculum subjects must include civic education (in addition to Religious Education, Bahasa Indonesia, and English) ${ }^{2}$.

1 Law number 20 year 2003 about National Education System. section 37 verse 2 .

2 Government regulation number 19 year 2005 about
Muhammadiyah as a religious organization in Indonesia, took part in building Indonesian society through empowerment in education. Its role in the field of education is undeniable. Until now Muhammadiyah education developed quite rapidly, ranging from elementary to higher education.

In the context of Higher Education, Muhammadiyah through the Council for Higher Education, Research and Development (Diktilitbang) Muhammadiyah Headquart (PP Muhammadiyah) published a textbook of Civic Education with thetitleofPendidikan Kewarganegaraan Menuju Kehidupan yang Demokratis dan Berkeadaban. The book was published in collaboration between the Council for Higher Education, Research and Development (Diktilitbang)

National Education Standard, section 9 verse 2. 
of Muhammadiyah, with the Institute for Education Research and Development (LP3) University Muhammadiyah of Yogyakarta, and The Asia Foundation. Of course the purpose of publishing these textbooks cannot be separated from efforts to realize the personalities of students who have values as mentioned in the decision of the General Director of Higher Education of National Education Ministry.

The aim of $\mathrm{Mu} \mathrm{h}$ ammadiyah by publishing the book of Civic Education for Universiti es should be appreciated. It was as had been mentioned "In order to make Muhammadiyah universities able to spearhead the process of democratization in this count $r y$, being able to integrate the universal values of Islam into various topics, able to internalize the values of Islam in student life".

\section{DISCUSSION}

\section{Civic Education at the University of Muhammadiyah}

There are eight chapters presented in the civics books. The focus of this paper is the content presented in chapter five, which is "Building a National Identity". The details are in the table below.

\begin{tabular}{|c|l|}
\hline Chapter & \multicolumn{1}{|c|}{ Sub chapter } \\
\hline & a. Definition of national identity \\
& b. Factors supporting the establishment of national identity \\
& c. Pluralistic and national integration \\
& d. Ideology \\
e. The types of ideology: \\
Chapter 5 & 1. Marxism, Communism, and Socialism \\
Build a National Identity. & 3. Nationalism and Capitalism \\
& 4. Feminism \\
& 5. Pluralism \\
& 6. Postmodernism \\
& f. Islam as an ideology \\
& g. Pancasila as an ideology \\
\hline
\end{tabular}

The material discussed on this ideology is very important, Especially in explaining the nation ideology of Indonesia as a nation's identity. This ideology needs to be understood comprehensively by the entire nation. Pancasila as the basic state not only be understood in the context of today, but also how to understand the history of the birth of Pancasila. And what about the role of Islamic figures in the formulation and understanding of Pancasila.

\section{Development of Civic education content}

\section{a. History of the formulation of the basic state}

To show its sincerity to give independence to Indonesia, so that on March 1, 1945 Japan formed Dokuritsu Zjunbi Tjoosakai (Investigation Agency Efforts Preparation of Indonesian Independence-
BPUPKI $)^{3}$. BPUPKI several times conducted meeting. The first council meeting took place between May 28 to June 1, 1945 to discuss the basic nation. The second council meeting took place between July 10 to 17,1945 to discuss the form of the nation, territory, Civic, the draft Constitution, economics and finance, defense, education, and teaching. ${ }^{4}$

3 Anwar Hardjono, Perjalanan Politik Bangsa, Jakarta: Gema Insani Press, 1997, pp. 36-37

4 Saafroedin Bahar, dkk. (Ed.), Risalah Sidang Badan Penyelidik Usaha-usaha Persiapan Kemerdekaan Indonesia (BPUPKI) Panitia Persiapan Kemerdekaan Indonesia (PPKI) 28 Mei 1945-22 Agustus 1945 (dalam Anwar Hardjono, Perjalanan Politik Bangsa, p. 37-38). According to Muhammad yamin in his book Pembahasan Undang-Undang Dasar Republik, as quoted by Endang Saifuddin Anshari, that BPUPKI second summit from july 10 to 16, 1945. Endang Saifuddin Anshari, Piagama Jakarta 22 Juni 1945, page. 14. In Deliar Noer note, from the number and composition of the member, almost all BPUPKI member are Indonesian. Ther were eight Japanese in it, one of them was Yoshio Ichibangase, residence of 
There are some national figures that convey the basic formulation of the country In the first council BPUPKI. It was recorded in the BPUPKI agenda that there are three characters that convey the basic formulation of nation were Mohammad Yamin, Supomo, and Sukarno. In addition BPUPKI then formed a committee which develops the basis of the country. This committee consists of nine people. ${ }^{5}$ Herein after known as the committee of nine, This committee then established and ratified the nation basic formula that consists of five points, and is known as The Jakarta Charteratau June 22, $1945 .^{6}$

Since June 22 until August 1945, the Jakarta Charter was accepted unanimously the basis of Indonesia, Even when there is a suggestion that the phrase of "for adherents" crossed out, Sukarno asserted that the Jakarta Charter as a result of a compromise between the Islam and ethnicity.

We found these sentences were entirely based on the deity. This was the result of a compromise between the two parties, so that

Cirebon, as vice leader. However those eight people can be neglegtec since they are not participating in lobbying. Deliar Noer, Partai Islam di Pentas Nasional, page. 30. Therefore the members of BPUPKI were 60 people, not including the leader and young leader. There were two young leader, they are Yoshio Ichibangase and R.P. Suroso (also as administration leader). Theleader was dr. K.R.T. Radjiman Wediodiningrat. It can be conclude that the total number of member were 63people. (Suhatno, $K i$ Bagus Hadikusumo, Hasil Karya dan Pengabdiannya, p. 79)

5 These nine committee were Soekarno, Moh. Hatta, A.A. Maramis, Abikusno Tjokrosujoso, Abdul Kahar Mudzakkir, Agus Salim, Ahmad Soebardjo, Wachid Hasjim, Moh. Yamin. Pada tanggal 29 Mei 1945, Muhammad Yamin deliver his idea that nation basis is : 1). Peri-Kebangsaan, 2). Peri-Kemanusiaan, 3). PeriKetuhanan, 4). Peri-Kerakyatan, 5). Kesejahteraan rakyat. Sementara menurut Soepomo susunan dasar negara adalah: 1). Persatuan, 2). Kekeluargaan, 3). Keseimbangan lahir bathin, 4). Musyawarah, 5). Keadilan rakyat. This formulation was delivered by Soepomo on 3st of Mei 1945. Mean while Soekarno on 1st June giving the speech to deliver his formulation which were: 1). Kebangsaan, 2). Internasionalisme atau Peri Kemanusiaan, 3). Mufakat atau demokrasi, 4). Kesejahteraan sosial, 5). Ketuhanan. (In Endang Saifuddin Anshari, Piagam Jakarta 22 Juni 1945, p. 165).

6 Anwar Hardjono, Perjalanan Politik Bangsa,Menoleh ke BelakangMenatap Masa Depan, Jakarta: Gema Insani Press, 1997, p. 39 with the compromise, the dispute between the two sides disapear. Every compromise is based on the giving and taking, geven and nemen. is a compromise based on the giving and taking. In short this is the best possible compromise. Thus, the committee will uphold the compromise called by the honorable member Muh. Yamin "Djakarta Charter", which accompanied the words of the honorable member Soekiman lord, gentlemen agreement, that is held firmly between the Islamic and national parties. ${ }^{7}$

Until Proclamation of Independence of Indonesia, the Jakarta Charter is still agreed as the basis of the nation. But the next day on August 18, 1945, the Jakarta Charter is amended. It happened when the Preparatory Committee for Indonesian Independence (PPKI) or dokuristu zyunbi inkai, ${ }^{8}$ conduct the council meeting in order to formulate the country's constitution. The changes in this case is the changes that occur in the first part of the Jakarta Charter, which originally read "Ketuhanan dengan kewajiban menjalankan syari'at Islam bagi pemeluk-pemeluknya" (Godhead with the obligation to run the Shari'ah for adherents) into "Ketuhanan Yang Maha Esa" (The Almighty God).

This change is not without cause. According to news received by Hatta from officers Kaigun, that representatives of the eastern part of Indonesia Christians and Protestants disagree with the seven words. They recognize that this part of the sentence is not binding on them, only the people who are Muslims. But the inclusion of such

7 Saafroedin Bahar, dkk. (Ed.), Risalah Sidang Badan Penyelidik Usaha-usaha Persiapan Kemerdekaan Indonesia (BPUPKI), pp. 264-265

8 After the draft of lawas approved by BPUPKI on July $16^{\text {th }}, 1945$, at 9 th August 1945 Panitia Persiapan Kemerdekaan Indonesia (PPKI) was formed or Dokuritsu Zyunbi Inkai. PPKI is planned as a board which approved the UUD. Initially government of Japan will approve PPKI on 18th of august 1945, and directly conducting summit. The agenda of the summit was the agenda which was prepared by BPUPKI, and on august 171945 Indonesia was independent. However on 15 of august 1945 japan was surrendered to allies, so that they could not their attempt to make Indonesia independent. In that condition, PPKI still conducting its summit forindonesia independence preparation.(see in Suhatno, Ki Bagus Hadikusumo, Hasil Karya dan Pengabdiannya, p. 114, 115 
provisions in the ordinance that became the principal basis of the Constitution to mean to discriminate against their minorities. If discrimination was set as well, they would rather stand outside the Republic of Indonesia. ${ }^{9}$

According to Hatta's assessment, because Japanese officer Kaigun was seriously like Indonesia's independence and unity while also reminiscent of the motto "united we stand and divided we fall", akhiranya Hatta felt that the officer's words affect his perspective. Hatta imagine how if the fight which was over 25 years, with great sacrifice like imprisoned and exiled to achieve independence, and then break out and being re- colonized. Because it was so serious, in the next morning on 18 August 1945, the Preparatory Committee before the trial began, Hatta invited Ki Bagus, Wahid Hasyim, Kasman Singodimedjo, and Teuku Muhammad Hasan to hold a preliminary meeting to discuss it. In order not to be separated, it was agreed by the five figures that by replacing the sentence according to Hatta piercing the hearts of the Christian, and replace it with The Almighty God.

\section{a. Role of Islamic Leaders}

1) Ki Bagus Hadikusumo

a) $\mathrm{Ki}$ Bagus Hadikusumo Thought about Islam as the basic ideology of nation

Ki Bagus was Indonesian Islamic leaders who played a major role could even be said to be a key figure in finding a way out of the impasse and tough debate on changes to the first principle of Pancasila. A history of the foundation of the nation is very important to be lifted and disseminated to the current generation, to be understood and seated proportionally, to maintain the continuity of the history of Pancasila itself.

On the same day with Supomo which were May 31,

9 Mohammad Hatta, Sekitar Proklamasi 17 Agustus 1945, Djakarta: Tintamas, 1969, p. 57
1945, Ki Bagus Hadikusumo got the opportunity to deliver his perspective in front BPUPKI about the nation basis. In his speech $\mathrm{Ki}$ Bagus did not call a nation basic formula as presented by Muhammad Yamin and Supomo. Ki Bagus only convey his argument that can deliver to a decision in setting the basic nation with an Islamic basis.

Some important points are conveyed by Ki Bagus in BPUPKI is: "If the gentlemen earnestly wants Indonesia have strong and closely unite people based on brotherhood and mutual cooperation, our country is founded on top of clues al- Quran and alHadith as I explained earlier. ${ }^{10}$ "Ki Bagus emphasize again, "build our country with the joint of Islamic religion with wisdom and truth '. ${ }^{11}$

With passion and determination, $\mathrm{Ki}$ Bagus said that Islam is the religion of the majority of the Indonesian, even the law of Islam is already live and act in Indonesia before the Dutch came and occupied it. So a lot of Islamic law which later became the nation's customs of Indonesia. Therefore, according to $\mathrm{Ki}$ Bagus to adjust Indonesia with the soul of its people, then the framers of the basic state must know really their soul to the Islamization of the people. Dive on the heartiest soul of the people to be essentially the

10 Saafroedin Bahar,Nannie Hudawati (peny.), Risalah Sidang Badan Penyelidik Usaha-usaha Persiapan Kemerdekaan Indonesia (BPUPKI), Panitia Persiapan Kemerdekaan Indonesia (PPKI) 28 Mei 1945-22 Agustus 1945, Jakarta: Sekretariat Negara Republik Indonesia, 1998, Edition IVth, p. 39

11 Ibid, p. 41 
governance of our country, So that our country can become a strong and prosperous country $^{12}$. And as a Muslim, who aspires Indonesia highways and independence, the independent Indonesia so that it can stand upright and steadfast, strong and robust, I expect this will be the establishment of Indonesia based on Islam. ${ }^{13}$

The perspective of $\mathrm{Ki}$ Bagus to make Islam as the state represents Islamicleaning faction which was anti-secular thought. Political affairs (nation) were the part that cannot be separated from religion. Ki Bagus provides an illustrative administration built on the foundation of Islam, which is a government led by the Prophet Muhammad S.A.W. based on the instructions of the Qur'an and Hadith. "Try that all of you (gentelments) investigate the history of Islam during the Prophet Muhammad's S.A.W. led his people to the instructions of the Koran, and at the time of Caliphs Rasyidin perform Islamic law in society, where gentlemen will get a good model to build the country and develop the community." 14

Here are some of the main ideas of $\mathrm{Ki}$ Bagus delivered in BPUPKI in order to explain the importance of Islam as a basis:

- The concept of human and society

- The people's representatives in the deliberations must be

$12 \quad$ Ibid, p. 46

13 Ibid, p. 47

14 Suhatno, Ki Bagus Hadikusumo, Hasil Karya dan Pengabdiannya, Jakarta: Depdikbud, 1982/1983, p. 17 based on candor, net of greed and selfishness

- Morals problems should be the main concern

- Islam teaches unity on the basis of a strong brotherhood

- Religion is the source of unity. Do not be afraid to express religious teachings

- The economy becomes an important part in Islamic teachings.

- Islam establish fair and justice governance, based on democracy and deliberation, and freedom of religion

- Islam be the best basis for our country, does not controversial and even very in accordance with our national

b) Ki Bagus Hadikusumo role in PPKI council summit on August $18^{\text {th }}, 1945$

Because it was so serious, the next morning on 18 August 1945, the Preparatory Committee before the summit began, Hatta invited Ki Bagus, Wahid Hasyim, Kasman Singodimedjo, and Teuku Muhammad Hasan to hold a preliminary meeting to discuss it. In an effort to guard against the split, it was agreed by the five figures that by replacing the sentence according to Hatta that it was piercing the hearts of the Christian, and replace it with The Almighty God.

At first the lobbying was a failed, because Ki Bagus adamant reject the proposed changes. Hatta and Teuku Muhammad Hasan out of the room leaving $\mathrm{Ki}$ Bagus alone. Kasman see the dead lock, he meet Ki Bagus on 
their own will and requested that he is willing to negotiate. Kasman explained that the situation was critical, because it is necessary to form the nation Constitution and the establishment of the Republic of Indonesia's independence. After six months later Consultative Assembly will convene to form the new Constitution. With Kasman approach, finally $\mathrm{Ki}$ Bagus expressed his willingness to negotiate again. Then Hatta, Teuku Muhammad Hasan asked to come, so there talks once again where Ki Bagus willing to accept not to include ". , , with the obligation to conduct the regulation of islam for adherents ". Instead Hatta and Teuku Muhammad Hasan willing to also meet Ki Bagus proposal, namely the Godhead with the additional with the Almighty, who was Ki Bagus itself states that the meaning Almighty God is Tauhid $^{15}$.

On that occasion Moh. Hatta were welcomed to make four amendments:

The word "Mukaddimah " is replaced with the word "pembukaan"

In the Preamble (the Jakarta Charter), the clause: "Based on the deity, with the obligation to carry out the Shari'ah for adherents" was changed to "Based on the God Almighty".

Article 6, paragraph 1, "The President is indigenous Indonesian and Muslim", the words "and Muslim" was crossed out.
- In line with the above changes, the article 29 to be a "state based on God Almighty", instead of "State based on God, with the obligation to carry out the Shari'ah for adherents" $^{\prime \prime} 16$

According to Hatta: "These changes are all important to unite all nations". After taking over the leadership, Soekarno added that the Constitution created this interim Constitution, the Constitution of lightning, Revolutiegrondwet ${ }^{17}$.

2) Kasman Singodimedjo

a) Kasman Singodimedjo role as opener of "deadlock"

Kasman is not included as a member of BPUPKI, but that does not mean Kasman has no role at all in relation to the basis of nation formulation. After BPUPKI has completed its tasks, the next task PPKI in drafting the Constitution. This is where Kasman entered into

16 Muhammad Yamin, Naskah Persiapan UndangUndang Dasar 1945, I-III, in Endang Saifuddin Anshari, Piagam Jakarta 22 Juni 1945, dan Sejarah Konsensus Nasional antara Nasionalis Islami dan Nasionalis "Sekular" tentang Dasar Negara Republik Indonesia, Bandung: Pustaka-Perpustakaan Salman ITB, 1981, pp. 42-43

17 Endang Saifuddin Anshari, Piagam Jakarta 22 Juni 1945 , p. 43. Initially soekarno stated in his opening speech : "Tuan-tuan sekalian tentu mengetahui dan mengakui, bahwa kita duduk di dalam suatu zaman yang beralih sebagai kilat cepatnya. Maka berhubung dengan itu saya minta kepada Tuan-Tuan sekalian, supaya kita pun bertindak di dalam sidang sekarang ini dengan kecepatan kilat. Jangan kita tertarik oleh kehendak yang kecil-kecil, tetapi marilah kita menurut garis-garis besar saja yang mengandung sejarah.. . . Soekarno juga meminta agar mengikuti garis-garis besar dari Undang-Undang Dasar yang telah dibuat oleh BPUPKI. Perubahan yang penting-penting saja yang dibahas agar pada hari itu selesai menyusun Undang-Undang Dasar dan memilih Presiden dan Wakil Presiden. Saafroedin Bahar, Nannie Hudawati (peny.), Risalah Sidang. . . p. p. 531 
its members as an additional member as proposed by Soekarno. But in the PPKI summit Kasman's role was not very outstanding. Why is that? It could be that is so, as said Prawoto that new Kasman dated August 18, 1945 that morning received a call for a meeting. And at the meeting point of the new Kasman see the first draft of the Constitution so that no meeting notes known that he did not contribute to contribute his thoughts.

It has been explained previously about the effort of Hatta, Wachid Hasjim, and Teuku Hasan in "persuading" Ki Bagus in order to accept the changes seven terms to be on God The Almighty, but in the end still Ki Bagus still resist to the change. This is where Kasman approached $\mathrm{Ki}$ Bagus for the changes to the receipt. With the Java subtle language, Kasman persuade Ki Bagus:

Kyahi, yesterday the proclamation ofindependence of Indonesia has occurred. Today should be quickly assigned the Constitution as the foundation of our country, and still must be determined who is the president and others to expedite the wheels of government. If Indonesian, especially leaders who bicker, then what?! Kyahi, now the Indonesian nation among the tongol-tongol and tingiltingil. Which tongol-tongol Dai Nippon army is still in the Earth Indonesia with modern weaponry. As for the tingiltingil is Allied including the Netherlands, with modern weaponry as well.
If we quarrel, surely we would be ridiculous. Kyahi, in the draft Constitution which we discuss about today contained a clause stating that six months later we get is the People's Consultative Assembly, precisely in order to make the Constitution is perfect. The present draft is the draft Constitution of the emergency. There is no time to make a perfect or satisfactory to all parties, especially in the emergency conditions!

Kyahi, it is not wise, if we are now as a majority of Muslims who have temporarily relented, namely removing the said seven words for the triumph of our common ideals, namely the achievement of Indonesia's independence as a sovereign nation, just and prosperous, peaceful quiet, blessed by God $^{18}$.

What is said by Kasman told Ki Bagus greatly influence the attitude of Ki Bagus, who eventually $\mathrm{Ki}$ Bagus accept changes to the first principle be on God, based on the considerations are logical and realistic in a situation that urgently need an wise attitude in maintaining the integrity of the state and unity of the nation. This is an important role of Kasman to remember in paving the way to Indonesia sovereign state with a solid basis and agreed upon by the founders of the country (founding fathers). Kasman's attempt as a way out of the impasse is likely to occur at a hearing of next PPKI.

18 Panitia Peringatan 75 Tahun Kasman, Hidup itu Berjuang, Kasman Singodimedjo 75 Tahun, Jakarta: Bulan Bintang, 1982, p. 129 
b) The perspective of Kasman Singodimedjo on the Jakarta Charter and Pancasila

Events change seven words of the Jakarta Charter felt so fast. Kasman has its own assessment of the rapid change that. He said from the standpoint of proponents who want change, it makes sense (logical), they took advantage of the psychological on the situation. And it shows that the situation had to be faced with the consequences of the freedom that has been officially proclaimed, and may not again repeated. According to Kasman:

Consider from the person who propose, it is logical that they were taking advantage of the psychological moment when the "ready for use" to promote its sensitive (gevoelig), precisely at a moment that the independence of Indonesia as a fact on the day before (17th August 1945) was proclaimed, it means to retreat was no longer possible and likely only one, which was to move on and face the consequences of follow up of the proclamation of independence ${ }^{19}$.

For Kasman, "It is precisely the consequence that require or requiring compactness and by onealloys of the entire Indonesian nation without exception, let alone to face the allied forces that the completeness of the weapon has been wafted already" tingil-tingil "was about to land on the mainland Indonesia, while the armies of Dai Nippon according in fact still "tongol-tongol" on the mainland Indonesia, also complete with weaponry that is yet to be submitted as a result had lost the war to the victorious allies. “20

Kasman's testimony and explanation is very important. Where he considers that the Christians of that time reading smart circumstances. The Christians interpret the seven words that would bind them legally also, the majority scattered in Eastern Indonesia. Though not. Their fears exaggerated. As explained by Kasman:

Non-Muslim minorities is smart. Smart to take advantage of psychological moment opportunities. In the meantime, talks in lobbying on the idea of such material iwas little bit tense and fierce. Tense and fierce as the Jakarta Charter that, on June 22, 1945 toch which thoroughly and thoughtfully has been defined and decided together, even first been arranged nicely by a "Committee of Nine" where also sit a national leader who is Christian, namely $\mathrm{Mr}$, A A. Maramis. , , , What of the formula seven words that can be considered as detrimental to non-Muslims is it? This group did not obligated or required to run the Islamic Shariah; isn't it! Even Islamic tolerance ensures that non-Muslims to worship according to his own practice ${ }^{21}$.

According Kasman if Muslims were given waranty 
in implementing the Shari'a, even non-Muslim minorities will be guaranteed their rights and obligations in the context of nation and society. Even light Kasman, "nonMuslims have a big interest, that Muslims will obey and practice their religion (Islam) orderly, because if not so then the non-Muslim minorities that would certainly be a victim of the majority bandit, bandits and rogues in addition to disorderly Islam." Tense and fierce, because inevitably people of principle, especially Ki Bagus Hadikusumo and I as member of Indonesian Independence Preparatory Committee, then remember the word of God contained in the letter of alQur'an al-Shaf paragraphs 2 and 3: $\mathrm{O}$ who believe, why do not you say something you do? great wrath of Allah because you say something that you did not do ${ }^{22}$.

In principle Kasman intends retaining the Jakarta Charter without any changes at all, as agreed by the Committee of Nine. But Kasman see the situation is so precarious, so that Indonesia that has been established is not an impasse. No great expectations Kasman at Soekarno statement saying six months later will then be made of the Constitution complete by the representatives of Indonesia through the MPR.

22 Ibid, p. 123. Soekarno in that lobbying was intentionally avoid and don't want to involve in the debating, probably because he was the Chairman of the Preparatory Committee for Indonesian Independence and particularly as participants of the Committee of Nine on the making of the Jakarta Charter, felt a bit awkward to deal Ki Bagus Hadikusumo and his friends, and therefore he only sent the son of Aceh Mr. TM. Hasan to lobbying process.
I was in the lobbying was anxious to maintain the Jakarta Charter as a whole unit, without deletion or removal of the said seven words, because the Jakarta Charter, it is natural and logical all for the nation and the people of Indonesia as a whole. But I also cannot deny or eliminate, the existence of an emergency situation and squeezed it once was ${ }^{23}$.

Clasps that's what make us the Muslims and PPKI it cannot be persisted principal, and finally we received better promise of Bung Karno, namely that 6 (six) months later representatives of the Indonesian nation gathered at the forum People's Consultative Assembly (MPR) for establishes the Constitution was perfect as perfect ${ }^{24}$.

The Changes of seven words of the Jakarta Charter be on The Almighty God, according to Kasman is a very important change. Because the The Almighty God, it contains all-Super. "The reforms it is a very important change. Important, not only because the proposer-the propose it pertained to a Muslim principled and consistent, like Ki Bagus Hadikusumo, Bung Hatta and me, but it's important when seen from the sense of the Almighty itself; not to mention the terms of the power, greatness and all-Super Power of the Almighty"25.

This is a sacrifice for the Muslim community in order to maintain the unity of the Indonesian nation. Islamic

23 Ibid, p. 123

24 Ibid, p. 124

25 Ibid 
leaders when it prefers Indonesia remain united not separated. So accept the changes seven words. Kasman and other figures who truly understand the meaning of "the Almighty" that is Tawhid that there is no allies for Him. And "Almighty" is theologically as well as a victory for Muslims. According Kasman the change was seriously considered as gifts and blessings of Allah be grateful to everyone, especially Muslims. Why is that? Because according to Kasman the word "Almighty" determine the meaning of the Godhead. Pancasila is now in geruisloos into philosophy of our country, not knowing deity Random divinity like goods magic, sculptures, idols, tombs sacred, guru, teacher occult, manmade considered potent or powerful, lessons psychotherapy or heresy, dogma, magical puzzles, calculations speculative, intellectualism, diletantisme and so forth; not! Again not godheads, but known by the Pancasila is the deity Almighty ${ }^{26}$.

The corebeliefinalmighty God that covers the whole of human life, and he became conviction of Unity Author on Sivaness. Thus described HAMKA, in describing the substance of principle Belief in God Almighty. According HAMKA Almighty God is the recognition of their power over the entire human power. Belief in God Almighty is the principle of the trust over the Unity of God, in Sivaness, in his actions and in his powers. Belief in God Almighty is

26 Ibid, pp. 124-125 recognizing that God is only one purpose of life of the whole universe, whether animate or inanimate. Belief in God Almighty three cases to one. The other three cases it is human, human life and nature. To only one God. ${ }^{27}$

The reality of the "battle" ideology at that time as a state that cannot be avoided, and ended in a decision in which the identity of Islam championed Islamic figures faced situation that "forces" that identity should be changed with the removal of the seven words of the Jakarta Charter, But the fact it should not be considered as a major defeat of Islamic figures in the face of national figures. Rather, it should be read as a gesture of statesmanship Islamic figures who loves his nation and country, namely the Republic of Indonesia. And sincerity they accept the change as the biggest prize of Muslims.

The important thing now is, should be submitted to the Indonesian Muslims not to be discouraged and lost in regret. Because if studied in depth the rights of Muslims in fighting for sharia law in Republic of Indonesia was wide open and guaranteed by the Constitution. As pointed by Kasman:

They forget that the "run Islamic shariah" for adherents of Islam that is fully guaranteed by the Constitution of 1945 alone Article 29, paragraph 1. They forget that it is also the Almighty God in Pancasila

27 HAMKA, Urat Tunggang Pancasila, Jakarta: Media Dakwah, 1985, p. 10 
and the Constitution itself guarantee the establishment of Allah's law which is Islam with its manifestations (Al-Qur'an). Instead they forget, that the Almighty God is the principle and the constitutional basis of the Republic of Indonesia, see Act of 1945 Article 29, paragraph 1 is in black and white reads: "The State based on Almighty God". ${ }^{28}$

Kasman expressly stated that the Jakarta Charter Act of 1945 was a long lasting. Likewise, their relationship with the Presidential Decree of July 5, 1959 is a unity that cannot be separated.

So there is no reason to be discouraged or to sputter or envy, in spite of a fact that cannot be found under the law actually Jakarta Charter with Presidential Decree dated July 5, 1959 has come back to life, including seven words on August 18, 1945 crossed out and erased. Because the Decree of July 5, 1959, which is "einlamig" or valid forever (meaning it cannot be revoked again) that the Jakarta Charter since July 5, 1959 into a last forever with the Constitution of 1945, yes, even the soul that animates the Constitution of 1945. Jakarta Charter and the Constitution of 1945 - July 5, 1945 Decree Aldus is a unit or a unity that cannot be split up..$^{29}$

c) Islam and Pancasila

As a character who participated in the discussion on the basis of state, Kasman argued that Pancasila as

28 Panitia Peringatan 75 Tahun Kasman,Hidup itu Berjuang, Kasman Singodimedjo 75 Tahun, p. 126

29 Ibid, pp. 126-127 the basis of the Republic of Indonesia does not have a conflict with Islam. It is precisely these five principles according to Kasman as part of a lesson in Islam. Muslims realized that Islam as a religion that contains values and a belief cannot be compared with Pancasila. Because I slam comes from God, whil e Pancasila is the result of human thought which se rve as the basis of the Indonesia. What is wrong is when $\mathrm{M}$ uslims assume Pancasila was more powerful, more perfect than Islam.

Pancasila it contains the five pre c epts all of which are als o as lesson in Islam, therefo $\mathrm{re}$ it is not possible to othe rs but Muslims can/ should be agreed upon by all five principles referred as a unity which has now become a philosophy of the Republic of Indonesia.

That Muslims besides that still have assumption that Islam is more perfect than Pancasila, it will not, and does not considered wrong by any o ne. The new one, when Muslims consider it excess $i$ ve Pancasila than Islam, because Islam is precisely decreed by Allah as the one and only religion which $b$ lessed by Allah (Qur'an Ali Imran: 19). ${ }^{30}$

30 Kasm a n Singodimedjo, Renungan dari Tahanan, Djakarta: Tintamas, 1967, p. 53. QS. Ali Imran (3): 19, adalah:

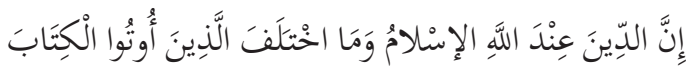

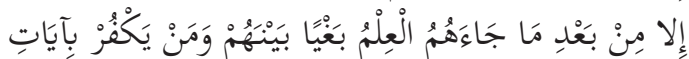

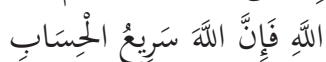
Verily the religion (the blessed) by Allah is Islam. no disputing those who have been given the Book except aft er knowledge had come to them, through envy (th at is) between them. Anyone who disbelieves the revelations of Allah, verily Allah is swift in reckoning. 
According to Kasman no conflict between Pancasila and Islam, even Pancasila has been strengthened by Islam. This will give benefit to Pancasila. A Muslim who practice the teachings of Islam, he has become a Pancasilaist, but according to a Pancasila- Kasman not necessarily he was a Muslim.

That Islam has more strength tan Pancasila, then it is good, no good at all to/for Pancasila itself and certainly not prohibited by Pancasila, even beneficial for Pancasila, because Pancasila will be strengthened and enriched by Islam. Thus it can be said that a Muslim is genuine automatic Pancasilais, while Pancasila is not always and may not be Muslim! ${ }^{31}$

d) The God Almighty source of precepts

The precept of Belief in God Almighty is the pillar (pillar)for other precepts. This Godhead precept must stand firm and strong. If precept Godhead cannot stand up straight then according Kasman built housing fell by as well as possible with the goal of a just, prosperous, gemah, ripah, loh jinawi.

Islam believers considers the supreme deity, from and within the Pancasila minimumnja as "pillars" (basic pillars) which at least standing in the middle of pillars which amount to four others who were. If the pillar was not up anymore, then it will definitely fall down the house which must be built

31 Kasman Singodimedjo, Renungan dari Tahanan, p. 54-55 according to the purpose: fair, prosperous, gemah, ripah, loh djinawi, governance, tentrem, karta Rahardja. On the other hand, the stands of a pillar it will definitely strengthen the four--pillars or column which located around it ${ }^{32}$.

The perspective of Kasman about precept of The Almighty God is the same with what was presented by Haji Agus Salim. In his writting Salim insists that "About the basic points of the first of these, the Almighty God, who is the subject of a special in this text, it be with following broader description, if God willing, in essence is indeed the subject of the first of this is" including " and has contained therein the following four basic points in our Pancasila. Even there are more basic other than the four. And it is also still a lot of cases in the country's affairs, homeland and society and which should constitute the basic anyway ". 33

B.5. Believe in God Almighty is not the Freedom of Religion

The precept of Belief in God Almighty should not be construed as religious freedom. For the meaning of the Almighty is One. The concept of monotheism is itself a conception of the Deity possessed only by Islam. This is different from the concept of God in other religions.

Thus Kasman's perspective, that the Islamic group has been asserted, that Almighty God was in no way

32 Ibid, pp. 66-67

33 Agus Salim and Mohammad Roem, Ketuhanan Yang Maha Esa dan Lahirnya Pancasila, Jakarta: Bulan Bintang, 1977, p. 10 
be taken to mean "freedom of religion" ${ }^{34}$

\section{3) Abdul Kahar Mudzakkir}

Roles and Thought of Abdul Kahar Mudzakkir in basic nation formulation

To view the role Mudzakkir particularly in discussing the basic nation, can be traced in the recorded agenda of the Constituent Assembly. Constituent is an institution in charge of preparing the country's constitution, which addressed on the basis of nation. Inside there are factions of political parties that passed the electoral 1955.It can be said at this summit the was happening for the ideology for the second time. In that summit Mudzakkir as one of spokesperson representing Masjumi Party.

In the Constituent Assembly in 1957, Mudzakkir speech was more outlining the history of the formulation of the Jakarta Charter which he said should not be forgotten by the people of Indonesia. That is why in the book From Muhammadiyah for Indonesia, this Mudzakkir speech entitled The Testimony of History. ${ }^{35}$

My Fraction had opinion because of the public has to know that I am among those who follow the formulation of Pancasila and also I included that participate make Jakarta Charter, it is expected that I would be given the opportunity to narrate the history of Pancasila. Pancasila by

34 Kasman Singodimedjo, Renungan dari Tahanan, p. 68

35 This speech of Mudzakkir was delivered in Konstituante summit in 1957. The Constituent Assembly is a trial conducted by the factions of political parties participating in elections and escaped in 1955. One of the tasks of the Constituent Agency is preparing the Constitution to replace the Constitution Temporary (Provisional Constitution) 1950. one of the material covered in this session is about the foundation of the state. But along the way, the Constituent Assembly was finally dissolved by Sukarno through a decree dated July 5, 1959. some competent person called and attributed with the character of honor and noble ${ }^{36}$.

Furthermore Mudzakkir review the formulation of the basis of the nation, as the chain of history that cannot be separated and forgotten.

Honorable Speaker and Gentlemen, at events history for each country, which were usually a $\mathrm{n}$ interrelated series, one with which other, so it is difficult if chose one event only and left the others. Just say so, because of the Pancasila alone, we cannot leave at events and the background of the earlier. Thus also questioned the independence of the country, we must also look at events that took place in 1944 and 1945 prior to the proclamation." ${ }^{37}$

At the summt at least three major ideological currents manifested in the existing factions, such as the ideology of nationalistsecular, nationalist-Islamic, and nationalist-communist. From the general view presented by each of the fractions, narrowed down to the two ideologies should be the basis of the state of Indonesia, Pancasila and Islam. But for the Communist Party of Indonesia had proposed that the first principle of Pancasila was changed to "freedom of religion". ${ }^{38}$

Therefore in the middle of ideological struggle, for Masjumi consistency and commitment in fighting for Islam as an ideology is very important.

Me and my colleague tasks from Party Assembly Muslimin Indonesia (Masjumi) is to serve illustrious Plenary Session and Gentlemen, our establishment with the mode of a wider and

36 Risalah Perundingan Tahun 1957, Djilid VII, Sidang IIIrd, p. 85

37 Ibid, p. 86

38 Risalah Sidang Tahun 1957, Djilid Ke-VII, Sidang IIIrd, p. 138 
deeper, what which we already noted in the Commission I of the Preparatory Committee for the Constitution, which is our will as already known to us all, in order that Republic of Indonesia our country is based on Islam: The state of democracy based on Islam. ${ }^{39}$

Note that in BPUPKI proposal $\mathrm{Ki}$ Bagus who wish that their constitutional guarantees for Muslims in running the sharia law should be the nation's attention. However, such proposals have always countered. On that occasion Mudzakkir delivered with full disappointed and suggested that all the words that relate to God, religion, or Islam dropped only from the Constitution ${ }^{40}$

The dynamics of the Constituent Assembly consumes enough energy and mind for all parties. Including energy and thoughts are poured by the Islamic leaders at the time. Until 1959 the Constituent Board still performs its duties to formulate a new constitution, and the ideological struggle still continues. But in this year appeared a political decision taken by the government, namely the release of Decree of President Soekarno on July 5, 1959. One of the contents of the decree is the dissolution of the Constituent Assembly and the return to

39 Risalah Sidang Konstituante IIIrd, p. 360

40 We are all called representatives of Muslims kindly ask, so that from the beginning of the statement of Indonesia's independence until the new provisions in the Constitution that mention God or religion or whatever, was dropped altogether, do some things that". (Saafroedin Bahar, Nannie Hudawati (peny.), Risalah Sidang Badan Penyelidik Usaha-usaha Persiapan Kemerdekaan Indonesia (BPUPKI),p.. 372). This Muzakir show his proposal that disappointed witnessed the proposals from Islamic circles have been rejected, and no longer able to hold back his anger. (Anwar Harjono, Perjalanan Politik Bangsa, Menoleh ke Belakang Menatap Masa Depan, p. 45) the Constitution of 1945. Thus, Pancasila became valid again as the state,

But it cannot be said that the struggle of Islamic figures in the strive for Islam became the basis of the state is considered a failure. Precisely Islamic leaders have succeeded in laying a solid foundation to make Jakarta as animating Charter Act of 1945. As stated Kasman:

, , , the Jakarta Charter since July 5, 1959 into a lively semati with the Constitution of 1945 , yes even the soul that animates the Constitution of 1945. Jakarta Charter and the Constitution of 1945 - July 5, 1945 Decree Aldus is a unit or a unity that cannot be split up. ${ }^{41}$

Previously, Soekarno also confirmed in his decree: "That we believe that the Jakarta Charter, dated June 22, 1945 animates Act of 1945 and is a continuum with the constitution;" 42

Likewise precept of The Almighty God is meaningful Tauhid, as described above by $\mathrm{Ki}$ Bagus. This means that it is the victory of the Muslims in fighting for the values of Islam in Indonesia.

Furthermore, for the people of Indonesia, Pancasila should be understood as the state, and not as the outlook of the nation. Because for Muslims who $h$ ave become view of life is Islam. According to automatic Kasman a true Muslim is Pancasilaist, while Pancasila is not, and is not necessarily a Muslim! ${ }^{43}$

41 The committee of 75 years of Kasman, Hidup itu Berjuang, Kasman Singodimedjo 75 Tahun, p.Ibid, p. 127

42 Soekarno, Dibawah Bendera Revolusi, Jilid II, Jakarta: Yayasan Bung Karno Joint with PT Media Pressindo, p.394

43 Kasman Singodimedjo, Renungan dari Tahanan, p. 55 
In Case Deliberation Inter Religious of the believers, December 19, 1983, stated that "Every religion has a religious foundation is universal, valid for all places and times and that should not be combined with something else in addition to understanding the fundamentals are authentic.

That the religious community, they have a principle according to their respective religions,. , , to become proselytes who obediently, as well as a citizen of the Pancasila. ${ }^{4}$

Similarly, Pancasila should not be used as an instrument of oppression for the people to make it as uniform agent of principle of socio-political organization of the nation. This would never happen in the New Order. Therefore Mohammad Natsir stated that it would change the meaning and function of the actual Pancasila. Natsir also worrisome if it continues to happen, the country gradually lead to a totalitarian system. ${ }^{45}$

44 Mohammad Natsir, Tempatkan Kembali Pancasila pada Kedudukannya yang Konstitusional, p.

45 Ibid, p. 3, 5

\section{CONCLUSION}

Civic education is taught in schools and colleges into one curriculum is very strategic. Because in this curriculum contains values that provide insight to the student or students as citizens with the right understanding, es p ecially about ideology or country basis. They must understand comprehensively challenged what was the basis of nation, how its history and why the ideological differences between one country and another.

Likewise Indonesia as a country that has a wide range of diversity, has its own ideologies and different from other countries. Basic nation, Pancasila received up to nowadays, not something that happens by chance. But experienced a long process and full of dynamics. Therefore admission to the basic nation at this time, should be accompanied with a basic understanding of the history of the country itself. The goal is to understand what is contained in the Pancasila, and to resist the various ideological contrasts with Pancasila, as the ideology of communism, liberalsime, secularism, pluralism, and so forth.

The development of these values into Civic Education in schools and colleges become very urgent. For the role of government and all elements of the community are expected.

\section{BIBLIOGRAPHY}

Anshari, Endang Saifuddin, Piagam Jakarta 22 Juni 1945, dan Sejarah Konsensus Nasional antara Nasionalis Islami dan Nasionalis "Sekular" tentang Dasar Negara Repyblik Indonesia, Bandung: Pustaka-Perpustakaan Salman ITB, 1981

Bahar, Saafroedin, Nannie Hudawati (peny.), Risalah Sidang Badan Penyelidik Usaha-usaha Persiapan Kemerdekaan Indonesia (BPUPKI), Panitia Persiapan Kemerdekaan Indonesia (PPKI) 28 Mei 1945-22 Agustus 1945, Jakarta: Sekretariat Negara Republik Indonesia, 1998, Edition IVth

Government Regulation, number 19 Year 2005 about National Education Standard

HAMKA, Urat Tunggang Pancasila, Jakarta: Media Dakwah, 1985

Hardjono, Anwar, Perjalanan Politik Bangsa,Menoleh ke BelakangMenatap Masa Depan, Jakarta: Gema Insani Press, 1997

Hatta, Mohammad, Sekitar Proklamasi 17 Agustus 1945, Djakarta: Tintamas, 1969

Law number 20 Year 2003 about National Education System

Natsir, Mohammad, Tempatkan Kembali Pancasila pada Kedudukannya yang Konstitusional. 
Panitia Peringatan 75 Tahun Kasman, Hidup itu Berjuang, Kasman Singodimedjo 75 Tahun,Jakarta: Bulan Bintang, 1982

Risalah Perundingan Years of 1957, Djilid VIIth, Sidang IIIth.

Salim, H. Agus, Mohammad Roem, Ketuhanan Yang Maha Esa dan Lahirnya Pancasila, Jakarta: Bulan Bintang, 1977

Singodimedjo, Kasman, Renungan dari Tahanan, Djakarta: Tintamas, 1967

Soekarno, Di Bawah Bendera Revolusi, Jilid II, Jakarta: Yayasan Bung Karno Bekerjasama PT Media Pressindo.

Suhatno, Ki Bagus Hadikusumo, Hasil Karya dan Pengabdiannya, Jakarta: Depdikbud, 1982/1983 